\title{
Kajian Awal Pemantauan Keausan Pahat Potong Berdasarkan Pengukuran Sinyal Arus Motor Listrik Pada Proses Pemesinan Bubut
}

\author{
Siswanto, Yanuar Burhanuddin*, Suryadiwansa Harun \\ Jurusan Teknik Mesin Fakultas Teknik Universitas Lampung \\ Jl. Prof. Soemantri Brojonegoro No.1 Gedung H Lantai 3 \\ Universitas Lampung, Kedaton, Bandar Lampung 35145 \\ *Corresponding author: yanuar.burhanuddin@eng.unila.ac.id
}

\begin{abstract}
This study aims to find alternative methods that can be applied to monitor and predict tool wear early so that quality control of the product can be maintained and the machining process is optimal. This research is motivated by the situation where the tool wear occurs still using the conventional way of seeing wear using a microscope toolmaker. Of course this method is slow because it has to stop the process to take the chisel and see the wear. This research is a study using experimental methods to obtain research data. The study was conducted on conventional lathes by measuring the electric current (I) and tool wear ( Vb). The machining parameters used are cutting speed $(V c)$, feed motion $(f)$ and depth of cut $(a)$ which are varied. Analysis of the data used is quantitative analysis using linear regression analysis. The results obtained are a mathematical model that can be used to predict tool wear. And from the results of the analysis using multiple linear regression analysis obtained 2 mathematical models. The first model is $I=3.181+0.007 \mathrm{Vc}+1.161 \mathrm{f}+0.436 \mathrm{e}$, this model is used to predict the value of electric current against machining parameters. The second model is $\mathrm{Vb}=-1.042+0.333 \mathrm{I}$ +0.466 2, this model is used to mediate the equation of model I against tool wear.
\end{abstract}

Keywords: Monitoring, Electric Current, Tool Wear, Mathematical Model

\begin{abstract}
Abstrak
Penelitian ini bertujuan untuk mencari alternatif metode yang dapat diaplikasikan untuk memantau dan memprediksi keausan pahat secara dini sehingga kontrol kualitas dari produk dapat tetap terjaga dan proses pemesinan menjadi optimal. Penelitian ini dilatarbelakangi oleh keadaan dimana terjadi keausan pahat masih menggunakan cara konvensional yaitu melihat keausan menggunakan mikroskop toolmaker. Tentu cara ini lambat karena harus menghentikan proses untuk mengambil pahat dan melihat keausannya. Penelitian ini merupakan penelitian dengan menggunakan metode eksperimen untuk mendapatkan data hasil penelitian. Penelitian dilakukan terhadap mesin bubut konvensional dengan mengukur arus listrik (I) dan keausan pahat $(\mathrm{Vb})$. Parameter pemesinan yang digunakan adalah kecepatan potong (Vc), gerak makan (f) dan kedalaman potong (a) yang divariasikan. Analisis data yang digunakan adalah analisis kuantitatif dengan menggunakan analisis regresi linear. Hasil penelitian diperoleh adalah suatu model matematik yang dapat dipakai untuk memprediksi keausan pahat. Dan dari hasil analisis dengan menggunakan analisis regresi linear berganda didapat 2 model matematik. Model yang pertama yaitu $I=3.181+0.007 \mathrm{Vc}+1.161 f+0.436 e_{1}$, model ini digunakan untuk memprediksi nilai arus listrik terhadap parameter pemesinan. Model yang kedua yaitu Vb= $1.042+0.333 I+0.466 e_{2}$, model ini digunakan untuk memediasi persamaan model I terhadap keausan pahat.
\end{abstract}

Kata Kunci: Pemantauan, Arus Listrik, Keausan Pahat, Model Matematik

\section{PENDAHULUAN}

Dalam perkembangannya, industri pemesinan merupakan salah satu alternatif pengolahan logam menjadi suatu produk yang siap pakai. Saat ini telah banyak produk dari suatu logam yang diproduksi melalui proses pemesinan, baik konvensional maupun non konvensional.

Dalam proses pemesinan, terjadi interaksi antara pahat dengan benda kerja dimana benda kerja terpotong sedangkan pahat mengalami gesekan. Akibat gesekan ini pahat mengalami keausan. Pada industri kecil yang kebanyakan menggunakan mesin konvensional, untuk mengetahui keausan pahat saat proses pemesinan berlangsung, biasanya seorang operator mesin hanya menggunakan feeling atau perasaannya. Dengan metode feeling tersebut tentu tidak dapat dipastikan kebenarannya, kadang memang benar mengalami keausan dan terkadang tidak benar, tergantung dari jam terbang atau pengalaman operator mesin.

Efek keausan pahat ditinjau dari ukuran performa secara teknik adalah berkaitan dengan konsekuensi menurunnya akurasi dimensi, meningkatnya kekasaran permukaan, meningkatnya gaya potong, meningkatnya suhu, getaran yang 
meningkat, kualitas komponen, meningkatnya arus listrik yang terpakai dan meningkatnya ongkos produksi. Semakin besar keausan pahat yang diderita maka semakin besar pula arus listrik yang dikonsumsi mesin (Rochim, 1993). Adanya hubungan antara keausan pahat dengan arus listrik ini dapat dijadikan suatu alternative metode dalam memonitor keausan pahat saat proses pemesinan berlangsung.

Untuk mengetahui atau memprediksi keausan pahat berdasarkan pengukuran sinyal arus motor, dapat dibangun suatu model persamaan matematik. Model tersebut dapat dibangun dengan analisis regresi. Regresi sendiri merupakan sebuah alat statistik yang memberikan penjelasan tentang pola hubungan (model) antar dua variabel atau lebih (Sudjana, 2005). Bentuk persamaan umum model regresi adalah sebagai berikut (Sugiyono, 2008) :

$\mathrm{Y}=\mathrm{b}_{0}+\mathrm{b}_{1} \mathrm{X}_{1}+\mathrm{b}_{2} \mathrm{X}_{2}+\mathrm{b}_{3} \mathrm{X}_{3}+\ldots+\mathrm{b}_{\mathrm{n}} \mathrm{X}_{\mathrm{n}}+\mathrm{e} \ldots$.. (1) Sedangkan untuk melihat besar hubungan antara arus listrik dengan keausan pahat dapat diketahui dengan analisis korelasi.

Untuk mengatasi permasalahan di atas, pemantauan keausan pahat potong pada proses pemesinan perlu dikembangkan. Pada penelitian ini penulis mencoba melakukan metode pemantauan keausan pahat potong berdasarkan pengukuran sinyal arus motor. Penelitian ini dilakukan dengan memanfaatkan sinyal arus listrik yang dikonsumsi oleh mesin pada saat proses pemesinan berlangsung.

\section{METODOLOGI PENELITIAN}

\section{Alat dan Bahan}

Bahan yang digunakan pada penelitian ini yaitu baja karbon rendah ST-37 dan material pahat yang digunakan yaitu HSS. Mesin bubut yang digunakan adalah mesin bubut konvensional merk PINACHO type S-90/200. Adapun alat-alat yang lainnya yang dipakai yaitu jangka sorong, clamp-on multimeter, alat pantau arus listrik, laptop, tools microscope dan protaktor.

\section{Prosedur Penelitian}

Langkah awal sebelum melakukan percobaan yaitu melakukan penentuan kondisi pemesinan. Kondisis pemesinan yang ditentukan meliputi penentuan variasi parameter pemesinan dan membuat rancangan percobaan. Berikut merupakan tabel variasi parameter pemesinan yang digunakan :

Tabel 1. Variasi Parameter Pemesinan

\begin{tabular}{|l|l|}
\hline Parameter Pemesinan & Variasi Parameter \\
\hline Speed of cut $(\mathrm{Vc})$ & 40, 59dan $89 \mathrm{rpm}$ \\
\hline Feed Rate $(\mathrm{f})$ & $0.3,0.45 \mathrm{dan} 0.6 \mathrm{~mm} / \mathrm{rev}$ \\
\hline Deep Of Cut(a) & $2 \mathrm{dan} 3 \mathrm{~mm}$ \\
\hline
\end{tabular}

Setelah dilakuakan penentuan kondisi pemesinan tahap selanjutnya yaitu melakukan setup pengambilan data. Adapun skema set-up pengambilan data dapat dilihat seperti pada Gambar 1 .

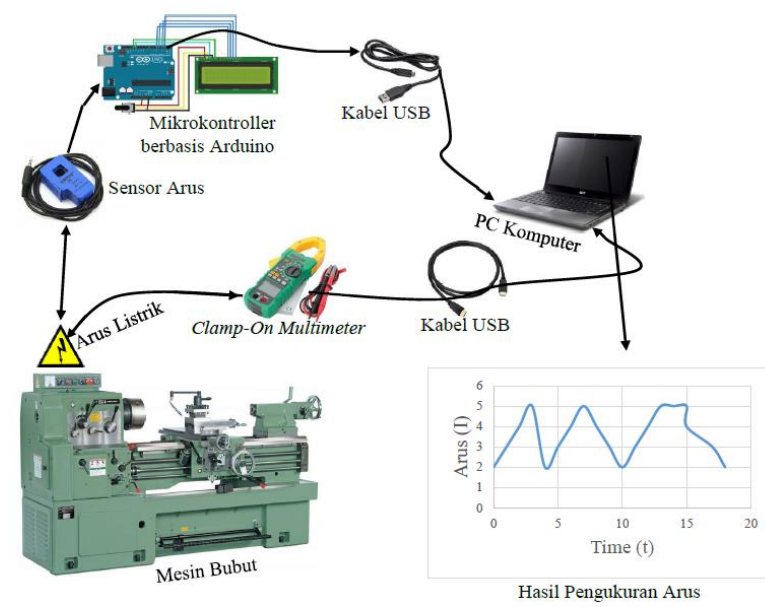

Gambar 1. Skema Set-Up Pengambilan Data

Kemudian tahap selanjutnya yaitu pelaksanaan percobaan. Pelaksanaan percobaan dilakukan dengan mengukur nilai arus motor dan mengukur keausan pahat yang terjadi. Setelah data percobaan didapat, dilakukan analisis regresi dan korelasi.

\section{HASIL DAN PEMBAHASAN}

Adapun data hasil percobaan yang telah dilakukan dapat dilihat pada Tabel 2 berikut :

Tabel 2. Data Hasil Percobaan

\begin{tabular}{|c|c|c|c|c|c|}
\hline Ke- & $\mathbf{V c}$ & $\mathbf{f}$ & $\mathbf{a}$ & $\mathbf{I}$ & $\mathbf{V b}$ \\
\hline 1 & 40.035 & 0.3 & 2 & 3.801023 & 0.179 \\
\hline 2 & 40.035 & 0.45 & 3 & 3.970613 & 0.173 \\
\hline 3 & 40.035 & 0.6 & 2 & 4.236341 & 0.358 \\
\hline 4 & 40.035 & 0.3 & 3 & 3.926385 & 0.284 \\
\hline 5 & 40.035 & 0.45 & 2 & 3.890161 & 0.209 \\
\hline 6 & 40.035 & 0.6 & 3 & 4.290813 & 0.372 \\
\hline 7 & 58.875 & 0.3 & 2 & 3.890879 & 0.341 \\
\hline 8 & 58.875 & 0.45 & 3 & 3.849478 & 0.299 \\
\hline 9 & 58.875 & 0.6 & 2 & 4.290813 & 0.389 \\
\hline 10 & 58.875 & 0.3 & 3 & 4.06399 & 0.433 \\
\hline 11 & 58.875 & 0.45 & 2 & 4.157491 & 0.401 \\
\hline 12 & 58.875 & 0.6 & 3 & 4.257273 & 0.358 \\
\hline 13 & 89.490 & 0.30 & 2 & 4.151115 & 0.267 \\
\hline 14 & 89.490 & 0.45 & 3 & 4.407245 & 0.447 \\
\hline 15 & 89.490 & 0.60 & 2 & 4.499114 & 0.343 \\
\hline 16 & 89.490 & 0.30 & 3 & 4.233116 & 0.373 \\
\hline 17 & 89.490 & 0.45 & 2 & 4.325047 & 0.313 \\
\hline 18 & 89.490 & 0.60 & 3 & 4.581115 & 0.626 \\
\hline
\end{tabular}

\section{Tahap Analisis Data}

Tahap analisis data yang dilakukan yaitu uji Anova, uji asumsi klasik dan Analisis Regresi. Uji 
anova ini dilakukan untuk mengetahui pengaruh parameter pemesinan terhadap arus listrik dan keausan pahat. Uji asumsi klasik dilakukan untuk menguji dan memastikan data yang dipakai untuk membangun suatu model regresi tidak terdapat penyimpangan asumsi klasik. Analisis regresi dan korelasi dilakukan untuk membangun suatu model persamaan matematik dan untuk mengetahui keeratan hubungan antara arus listrik dan keausan pahat. Gambar 2 dan 3 merupakan output Uji anova yang dilakukan dengan menggunakan SPSS.

\begin{tabular}{|c|c|c|c|c|c|}
\hline \multirow[b]{3}{*}{ Model } & \multicolumn{3}{|c|}{ Coefficients ${ }^{\mathrm{a}}$} & \multirow[b]{3}{*}{$\mathrm{T}$} & \multirow[b]{3}{*}{ Sig. } \\
\hline & \multicolumn{2}{|c|}{$\begin{array}{l}\text { Unstandardized } \\
\text { Coefficients }\end{array}$} & \multirow{2}{*}{$\begin{array}{c}\text { Standardized } \\
\text { Coefficients } \\
\text { Beta }\end{array}$} & & \\
\hline & B & $\begin{array}{l}\text { Std. } \\
\text { Error }\end{array}$ & & & \\
\hline 1 (Constant) & 3.087 & .168 & & 18.351 & .000 \\
\hline $\begin{array}{l}\text { Kecepatan } \\
\text { Potong }\end{array}$ & .007 & .001 & .656 & 6.126 & .000 \\
\hline $\begin{array}{l}\text { Gerak } \\
\text { Makan }\end{array}$ & 1.161 & .196 & .634 & 5.914 & .000 \\
\hline $\begin{array}{l}\text { Kedalaman } \\
\text { Potong }\end{array}$ & .038 & .048 & .084 & .781 & .448 \\
\hline
\end{tabular}

a. Dependent Variable: Arus Listrik

Gambar 2. Parameter Pemesinan terhadap Arus Listrik

\section{Coefficients $^{\mathrm{a}}$}

\begin{tabular}{|l|r|r|r|r|r|}
\hline & \multicolumn{2}{|c|}{$\begin{array}{c}\text { Unstandardized } \\
\text { Coefficients }\end{array}$} & $\begin{array}{c}\text { Standardized } \\
\text { Coefficients }\end{array}$ & & \\
\cline { 2 - 4 } Model & \multicolumn{1}{c|}{ B } & \multicolumn{1}{|c|}{$\begin{array}{c}\text { Std. } \\
\text { Error }\end{array}$} & \multicolumn{1}{|c|}{ Beta } & \multicolumn{1}{c|}{ T } & \multicolumn{1}{c|}{ Sig. } \\
\hline 1 (Constant) & -1.749 & .373 & & -4.690 & .000 \\
$\begin{array}{l}\text { Kecepatan } \\
\text { Potong }\end{array}$ & .020 & .003 & .660 & 7.481 & .000 \\
$\begin{array}{l}\text { Gerak } \\
\text { Makan }\end{array}$ & 3.317 & .435 & .672 & 7.626 & .000 \\
$\begin{array}{l}\text { Kedalaman } \\
\text { Potong }\end{array}$ & .075 & .107 & .062 & .700 & .496 \\
\hline
\end{tabular}

a. Dependent Variable: Keausan Pahat

Gambar 3. Parameter Pemesinan terhadap Aus Pahat

Setelah dilakukan uji anova terdapat parameter pemesinan yang tidak berpengaruh terhadap arus listrik dan keausan pahat yaitu parameter kedalaman potong. Dalam hal ini maka kedalaman potong tidak dimasukan ke analisis selanjutnya.

\section{Analisis Regresi}

Analisis regresi dilakukan untuk mengetahui pengaruh dan membangun suatu model persamaan matematik. Analisis regresi dilakukan secara 2 tahap yaitu analisis regresi model I dan analisis regresi model II. Analisis regresi model I untuk memperolaeh suatu model persamaan antara kecepatan potong $\left(\mathrm{X}_{1}\right)$ dan gerak makan $\left(\mathrm{X}_{2}\right)$ terhadap arus listrik $\left(\mathrm{Y}_{1}\right)$. Sedangkan Regresi model II dilakukan untuk memperoleh suatu model persamaan antara arus listrik $\left(\mathrm{Y}_{1}\right)$ terhadap keausan pahat $\left(\mathrm{Y}_{2}\right)$.

\section{Analisis regresi model I}

Analisis regresi model 1 (satu) digunakan untuk mengetahui kekuatan hubungan antara variabel kecepatan potong $\left(\mathrm{X}_{1}\right)$ dan kedalaman makan $\left(\mathrm{X}_{2}\right)$ terhadap arus listrik $\left(\mathrm{Y}_{1}\right)$. Pada analisis regresi model 1 (satu) persamaan regresiny adalah :

Arus listrik $=b_{0}+b_{1}$ kecepatan potong + $\mathrm{b}_{2}$ gerak makan $+\mathrm{e}_{1}$

Gambar 4 merupakan output yang dihasilkan dari analisis regresi model I .

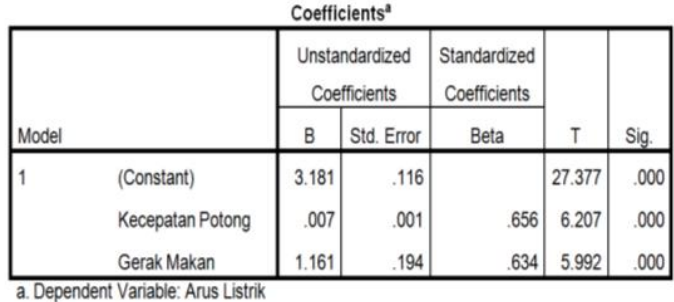

Gambar 4. Output Analisis Regresi Model I Berdasarkan hasil uji SPSS diatas, maka persamaan regresi yang mencerminkan variabel-variabel dalam penelitian ini adalah :

$$
\begin{gathered}
\mathrm{Y}_{1}=3.181+0.007 \mathrm{X}_{1}+1.161 \mathrm{X}_{2}+\mathrm{e}_{1} \\
\text { atau } \\
\mathrm{I}=3.181+0.007 \mathrm{Vc}+1.161 \mathrm{f}+\mathrm{e}_{1} \ldots . .
\end{gathered}
$$

Keterangan:

$\mathrm{Y}_{1} / \mathrm{I}=$ Arus Listrik

$\mathrm{X}_{2} / \mathrm{f}=$ Gerak Makan

$\mathrm{X}_{1} / \mathrm{Vc}=$ Kecepatan Potong

$\mathrm{e}_{1} \quad=$ Error

Persamaan diatas dapat disimpulkan sebagai berikut

- $\quad$ Konstanta/Intercep $=3.181$

Intersep sebesar 3.181 secara matematis menyatakan bahwa apabila nilai $\mathrm{Vc}$ (kecepatan potong) danf (gerak makan) sama dengan 0 maka nilai Isama dengan 3.181. Yang berarti bahwa arus listrik adalah bernilai sebesar 3.181 .

- Kecepatan Potong (Vc) terhadap Arus Listrik (I) $=0.007$

Nilai koefisien kecepatan potong untuk variabel Vc sebesar 0.007. Hal ini mengandung arti bahwa setiap kenaikan kecepatan potong satu satuan maka variabel arus listrik (I) akan naik sebesar 0.007 dengan asumsi bahwa variabel bebas yang lain dari model regresi adalah tetap. Nilai signifikansi variabel Vc pada model regresi sebesar 0.000 $(<0.05)$ yang berarti bahwa kecepatan potong 
berpengaruh secara signifikan terhadap arus listrik.

- Gerak Makan (f) terhadap Arus Listrik (I) = 1.161

Nilai koefisien gerak makan untuk variabel $\mathrm{f}$ sebesar 1.161. Hal ini mengandung arti bahwa setiap kenaikan gerak makan satu satuan maka variabel arus listrik (I) akan naik sebesar 1.161 dengan asumsi bahwa variabel bebas yang lain dari model regresi adalah tetap.Nilai signifikansi variabel $f$ pada model regresi sebesar $0.000 \quad(<0.05)$ yang berarti bahwa gerak makan berpengaruh secara signifikan terhadap arus listrik.

\section{Analisis Regresi Model II}

Analisis regresi model II (dua) digunakan untuk memperoleh model persamaan antara arus listrik (X) terhadap keausan pahat (Y) . Pada analisis regresi model II (dua) persamaan regresinya adalah

$$
\text { Keausan pahat }=a+b(\text { arus listrik })+e_{2}
$$

Hasil analisis regresi dapat dilihat pada Gambar 5.

\begin{tabular}{|c|c|c|c|c|c|}
\hline \multicolumn{6}{|c|}{ Coefficients $^{\mathrm{a}}$} \\
\hline \multirow[b]{2}{*}{ Model } & \multicolumn{2}{|c|}{$\begin{array}{l}\text { Unstandardized } \\
\text { Coefficients }\end{array}$} & \multirow{2}{*}{$\begin{array}{c}\text { Standardized } \\
\text { Coefficients } \\
\text { Beta }\end{array}$} & \multirow[b]{2}{*}{ t } & \multirow[b]{2}{*}{ Sig. } \\
\hline & B & Std. Error & & & \\
\hline (Constant) & -1.042 & .332 & & -3.140 & .006 \\
\hline Arus Listrik & .333 & .080 & .722 & 4.178 & .001 \\
\hline
\end{tabular}

Gambar 5. Output Analisis Regresi Model II

Berdasarkan hasil uji SPSS diatas, maka persamaan regresi yang mencerminkan variabelvariabel dalam penelitian ini adalah :

$$
\begin{gathered}
\mathrm{Y}_{2}=-1.042+0.333 \mathrm{Y}_{1}+\mathrm{e}_{2} \ldots \ldots \\
\text { atau } \\
\mathrm{Vb}=-1.042+0.333 \mathrm{I}+\mathrm{e}_{2} \ldots \ldots
\end{gathered}
$$

Keterangan :

$$
\begin{aligned}
& \mathrm{Y}_{2} / \mathrm{Vb}=\text { Keausan Pahat } \\
& \mathrm{Y}_{1} / \mathrm{I}=\text { Arus Listrik } \\
& \mathrm{e}_{2}=\text { Error }
\end{aligned}
$$

Persamaan diatas dapat disimpulkan sebagai berikut

Konstanta/Intercep $=-1.042$

Intersep sebesar -1.042 secara matematis menyatakan bahwa apabila I (arus listrik) sama dengan 0 maka nilai $\mathrm{Vb}$ (keausan pahat) sama dengan -1.042. Yang berarti bahwa keausan pahat adalah -1.042. Dalam hal ini, tidak mungkin keausan pahat bernilai negatif. Maka dari itu menurut Gujarati (2006), intersep tidak selalu harus diinterpretasikan, nilai intersep tidak selalu berarti karena seringkali jangkauan nilai variabel bebas tidak memasukkan nol sebagai salah satu nilai yang diamati. Jadi nilai intersep dalam hal ini tidak harus diinterpretasikan karena jangkauan nilai I (arus listrik) tidak akan mungkin bernilai nol.

- Arus Listrik (I) terhadap Keausan Pahat $(\mathrm{Vb})=$ 0.333

Nilai koefisien arus listrik untuk variabel I sebesar 0.333. Hal ini mengandung arti bahwa setiap kenaikan arus listrik satu satuan maka variabel keausan pahat (Vb) akan naik sebesar 0.333 .

\section{Validasi Model Regresi}

Validasi model regresi dilakukan untuk mengetahui tingkat kesalahan prediksi dari suatu model yang telah dibangun.

\section{Validasi Regresi Model I}

Tabel 5 dibawah merupakan tabel hasil prediksi nilai arus yang diperoleh dari persamaan model I :

$$
\mathrm{I}=3.181+0.007 \mathrm{Vc}+1.161 \mathrm{f}+\mathrm{e}_{1} \ldots . .(6)
$$

Tabel 5. Perbandingan Nilai Arus Listrik Aktual Terhadap Prediksi Model I

\begin{tabular}{|c|c|c|c|}
\hline $\begin{array}{c}\text { Percobaan } \\
\text { Ke- }\end{array}$ & $\begin{array}{c}\text { Nilai Arus } \\
\text { Aktual }\end{array}$ & $\begin{array}{c}\text { Nilai } \\
\text { Arus } \\
\text { Prediksi }\end{array}$ & Error (\%) \\
\hline 1 & 3.80 & 3.81 & 0.22 \\
\hline 2 & 3.97 & 3.98 & 0.33 \\
\hline 3 & 4.24 & 4.16 & 1.85 \\
\hline 4 & 3.93 & 3.81 & 2.98 \\
\hline 5 & 3.89 & 3.98 & 2.40 \\
\hline 6 & 4.29 & 4.16 & 3.10 \\
\hline 7 & 3.89 & 3.94 & 1.30 \\
\hline 8 & 3.85 & 4.12 & 6.91 \\
\hline 9 & 4.29 & 4.29 & 0.03 \\
\hline 10 & 4.06 & 3.94 & 3.02 \\
\hline 11 & 4.16 & 4.12 & 1.01 \\
\hline 12 & 4.26 & 4.29 & 0.76 \\
\hline 13 & 4.15 & 4.16 & 0.11 \\
\hline 14 & 4.41 & 4.33 & 1.76 \\
\hline 15 & 4.50 & 4.50 & 0.11 \\
\hline 16 & 4.23 & 4.16 & 1.83 \\
\hline 17 & 4.33 & 4.33 & 0.11 \\
\hline 18 & 4.58 & 4.50 & 1.68 \\
\hline & & & \\
\hline
\end{tabular}

Pada tabel 5 diatas menunjukan bahwa nilai error atau kesalahan prediksi yaitu sebesar 0.03 sampai $6.91 \%$. Jika dirata-ratakan nilai error yang terjadi sebesar $1.638 \%$. Hal ini dapat dikatakan model persamaan regresi yang terbangun cukup baik dalam memprediksi nilai arus listrik.

2. Validasi Regresi Model II

Dibawah merupakan tabel hasil prediksi nilai arus yang diperoleh dari persamaan model II : 


$$
\mathrm{Vb}=-1.042+0.333 \mathrm{I}+\mathrm{e}_{2} \ldots \ldots .(7)
$$

Tabel 6 Perbandingan Nilai Arus Listrik Aktual Terhadap Prediksi Model II

\begin{tabular}{|c|c|c|c|}
\hline $\begin{array}{c}\text { Percobaan } \\
\text { Ke- }\end{array}$ & $\begin{array}{c}\text { Keausan } \\
\text { Pahat } \\
\text { Aktual }\end{array}$ & $\begin{array}{c}\text { Keausan } \\
\text { Pahat } \\
\text { Prediksi }\end{array}$ & $\begin{array}{c}\text { Error } \\
(\%)\end{array}$ \\
\hline 1 & 0.18 & 0.22 & 24.99 \\
\hline 2 & 0.17 & 0.28 & 61.97 \\
\hline 3 & 0.36 & 0.37 & 2.99 \\
\hline 4 & 0.28 & 0.27 & 6.52 \\
\hline 5 & 0.21 & 0.25 & 21.26 \\
\hline 6 & 0.37 & 0.39 & 3.99 \\
\hline 7 & 0.34 & 0.25 & 25.61 \\
\hline 8 & 0.30 & 0.24 & 19.77 \\
\hline 9 & 0.39 & 0.39 & 0.56 \\
\hline 10 & 0.43 & 0.31 & 28.10 \\
\hline 11 & 0.40 & 0.34 & 14.60 \\
\hline 12 & 0.36 & 0.38 & 4.94 \\
\hline 13 & 0.27 & 0.34 & 27.46 \\
\hline 14 & 0.45 & 0.43 & 4.78 \\
\hline 15 & 0.34 & 0.46 & 33.00 \\
\hline 16 & 0.37 & 0.37 & 1.44 \\
\hline 17 & 0.31 & 0.40 & 27.23 \\
\hline 18 & 0.63 & 0.48 & 22.76 \\
\hline & & &
\end{tabular}

Pada tabel 6 diatas menunjukan bahwa nilai error atau kesalahan prediksi yaitu sebesar 0.56 sampai 33\%.Jika dirata-ratakan nilai error yang terjadi sebesar $18.443 \%$.

Kesalahan/error yang terjadi cukup besar, dalam hal ini, dicoba melakukan pengembangan regresi linear kedalam bentuk regresi polinomial untuk mendapatkan suatu model persamaan baru dengan nilai error yang kecil. Regresi polinomial merupakan model regresi linear yang dibentuk dengan menjumlahkan pengaruh masing-masing variabel prediktor yang dipangkatkan meningkat sampai orde ke- $k$. Secara umum, regresi polinomial ditulis dalam bentuk :

$$
\mathrm{Y}=\mathrm{b}_{0}+\mathrm{b}_{1} \mathrm{X}+\mathrm{b}_{2} \mathrm{X}^{2}+\ldots .+\mathrm{b} k \mathrm{X}^{k}+\mathrm{e}
$$

\section{KESIMPULAN}

Berdasarkan hasil penelitian yang telah dilakukan, maka dapat diambil kesimpulan sebagai berikut :

Model persamaan matematik yang diperoleh:

- $\quad \mathrm{I}=3.181+0.007 \mathrm{Vc}+1.161 \mathrm{f}+0.436 \mathrm{e}_{1}$. Digunakan untuk memprediksi nilai arus listrik terhadap parameter pemesinan.

- $\quad \mathrm{Vb}=-1.042+0.333 \mathrm{I}+0.466 \mathrm{e}_{2}$. Digunakan untuk memediasi persamaan model I terhadap keausan pahat.

Persamaan matematik model I yang diperoleh menghasilkan nilaiprediksi dengan error rata- rata sebesar $1.638 \%$ menyimpulkan bahwa persamaan matematik model I yang terbangun cukup baik dalam memprediksi nilai arus listrik. Persamaan matematik model II yang diperoleh menghasilkan nilai prediksi dengan error ratarata sebesar $18.43 \%$ menyimpulkan bahwa persamaan matematik model II yang terbangun kurang baik dalam memprediksi nilai keausan pahat. Arus listrik dapat dilakukan untuk pemantauan keausan pahat. Dibuktikan dengan adanya hubungan yang kuat antara arus listrik dengan keausan pahat.

\section{DAFTAR PUSTAKA}

[1] Rochim, T. 1993. Teori dan Teknologi Proses Pemesinan. Jakarta: HEDSP.

[2] Sudjana. 2005. Metode Statistika. Bandung: Tarsito.

[3] Sugiyono. 2008. Statistika untuk Penelitian. Bandung: Alfabeta. 